earthquakes have occurred in the past at Chaman (Baluchistan) on December 20, 1892; at Kachhi (Baluchistan) on October 21, 1909; at Mach (Baluchistan) on August 27, 1931; as well as at Cutch on June 16, 1819, and at Quetta on May 31, 1935.

\section{Southwest Research Institute, Texas}

THE Southwest Research Institute, San Antonio, Texas, has ppoved of the establishment of a division of oceanography and meteorology and a division of petroleum technology in Houston, Texas. The hivision of oceanography and meteorology will be of particular scientific importance, since oceanographic data on the Gulf of Mexico are particularly scanty. The research in this field will commence with a survey of currents, the shifting topography of the shelf area, and marine life in the Corpus Christi area, and the work will then be extended eastwards. The schooner Harpoon has already been earmarked for research in the Gulf. The oceanographic work will be in two phases: first, the project of the Institute, which will be freely published; and second, the fulfilment of private contracts, which will be paid for by the firms concerned on a cost basis. The establishment of the division of petroleum technology in Houston is the result of the widespread activity with regard to petroleum in that area and the fact that the local industries have immediate problems which can well be undertaken by the Southwest Research Institute. The Institute itself is a nop profit, endowed research organisation.

\section{7}

\section{Unesco Fellowship $\mathrm{Ha}$ dbaok}

THE secretarialy Unesco has prepared a most useful haldpook providing details of all available oppgrtunites for trans-national study and organised arranfements made in this field, which should be of real assistance to those wishing to travel out of their own countries for purposes of study. The handbook, which is intended to be the first of a series, constitutes a repository of information on the considerable investments by governments, universities, foundations and charitable institutions in the promotion of international study. Whether these fellowships or awards are designed to assist the reconstruction or development of a particular country, to encourage scientific research, to stimulate artistic exchange or to promote international understanding in general, they represent a striking volume of assistance from many sources to individuals chosen for their capacity to advance the course of learning and to profit from the cultural heritage of countries other than their own. Copies of the handbook, which may be obtained from H.M. Stationery Office, price $5 s$., show that more than ten thousand opportunities for international study are available for the year 1948-49.

\section{Gamma-Emitting Materials for Industry}

THE Ministry of Supply has recently announced that radium and radon can now be supplied for use in industrid radiography. Radium is available on hire only, and will remain the property of the Government It can be hired for periods of not less than six months, and the average time to fulfil an order is two months. Radon is sold outright, and notice of one week is required for an order. Demonstrations of gamma-radiography for industrialists can be seen by appointment at the Ministry's Armament Research
Establishment, Woolwich, London, and at the National Physical Laboratory, Teddington, Middlesex. Radium and radon are supplied by the Radiochemical Centre, Amersham, Bucks, and applications for purchase or loan should be addressed to that establishment.

\section{Spectrographic Research Unit of the Medical Research Council}

By arrangepent with the London Hospital, the Medical Rovarch Council has established there a Spectrographic Research Unit under the direction of Dr. E. R. Holiday. The primary function of the Unit is to undertake original research work in the field of absorption spectrophotometry as applied to biological problems of medical interest; but advice and assist. ance will also be given to other branches of the Council's organisation using such methods. The Unit has been based on the spectrographic department originally established by the London Hospital, and during the last five years partly supported by the Council for the purposes which are now being developed.

\section{Education of the Young Worker}

A SECOND Conference on the Education of the Young. Worken with a special subject for consideration, The Entry into Work, Guidance and Initiation, will be held at Manchester College, Oxford, during July 23-29, 1949. Like its predegessor in 1948, it has been arranged under the auspices of the University Department of Education, the director of which is Mr. M. L. Jacks, and aims at bringing together representatives from industry, education, central and local government departments, voluntary organisations and other bodies which are concerned in the education and welfare of young people between the ages of fifteen and twenty who are no longer in full-time education. The Conference will work in commissions; but whereas last year each commission had a special subject to consider, this year the subjects will be the same for all commissions, each of which will report its findings to the whole Conference at plenary sessions. Further information can be obtained from the Director, University Department of Education, 15 Norham Gardens, Oxford.

\section{British Social Hygiene Council: Summer School in Austria}

OwING to yarious difficulties connected with foreign trayd, the Summer School on "The Family and the Pation", which the British Social Hygiene Counci had arranged to hold at the University, Berpe, Switzerland, during August 17-September 1, has now been transferred to Pertisau in the Austrian Tyrol. There will be no change in the lecture programme, which will deal with different aspects of family life, such as marriage problems, nutrition, human heredity, population, the welfare of old people, the problem family, and juvenile delinquency. As in the past, only the first week will be devoted to study, the second week being entirely free for rest and recreation and for excursions to places of beauty and interest in the surrounding countryside. The cost, including travel, hotel accommodation and tuition, will be approximately $£ 34$. Further information can be obtained from the Secretary, British Social Hygiene Council, Tavistock House North, Tavistock Square, London, W.C.1. 